\title{
Non-Nutritive Bioactive Compounds in Pulses and Their Impact on Human Health: An Overview
}

\author{
Jagdish Singh, Partha Sarathi Basu \\ Division of Basic Sciences, Indian Institute of Pulses Research, Kanpur, India. \\ Email: jagdish1959@gmail.com, basups@sify.com \\ Received October $18^{\text {th }}, 2012$; revised November $18^{\text {th }}, 2012$; accepted November $26^{\text {th }}, 2012$
}

\begin{abstract}
This review describes the non-nutritive biologically active components in grain legumes and discusses about the bioactivity of phenols, isoflavones, phytosterols, phytic acid, saponins, tannins, protease inhibitors and bioactive complex carbohydrates in different pulse grains. These bioactive components have wide ranging biological activities and consequently many different targets and mechanism of action. The potential beneficial effect of these compounds especially their antioxidant properties and their role in the prevention of non-communicable chronic diseases such as coronary heart disease, stroke, cancer and diabetes has been discussed.
\end{abstract}

Keywords: Pulses; Grain Legumes; Bioactive Compounds; Anti Nutritional Compounds; Phenolics; Antioxidants; Antioxidant Activity

\section{Introduction}

The term pulses is limited to legume crops harvested solely for dry grains and excludes legumes used for oil extraction (soybean \& groundnut) and those harvested green for food (green peas and green beans). The major pulses used for human consumption include chickpea (Cicer arietinum), pigeon pea (Cajanus cajan), lentil (Lens culnaris), green gram (mung bean) (Vigna radiata), black gram (urdbean) (Vigna mungo), fieldpea (Pisum sativum), lupin (Lupinus spp.), kidney bean (Phaseolus vulgaris), lima bean (Vigna lunatus), adzuki bean (Vigna angularis), Rice bean (Vigna umbellata), moth bean (Vigna acontifolia), dry broad bean (Vicia faba) and dry cowpea (Vigna unguiculata). Recent researches have associated the consumption of pulses with a decreased risk for a variety of chronic degenerative diseases such as cancer, obesity, diabetes and cardiovascular diseases [13]. Pulse grains are rich source of protein, dietary fibre, complex carbohydrates, resistant starch and a number of vitamins and minerals viz., folate, potassium, selenium and zinc. In addition to the macronutrients, pulses contain a wide variety of non-nutritive bioactive components such as enzyme inhibitors, phytic acid, lectins, phytosterols, phenolic compounds and saponins [4]. These nonnutritive bio-active compounds earlier considered as anti-nutrients because of their activity to reduce protein digestibility [5] and mineral bioavailability have recently been shown to have health protective effects [6]. Phytic acid exhibits antioxidant activity and protects DNA da- mage [7], phenolic compounds have antioxidant and other important physiological and biological properties [8], saponins have hypocholesterolaemic effect and anticancer activity [9]. This review seeks to discuss and document the potential benefits to human health derived from the consumption of pulse grains and examine the bioactivity of pulse lectins, phytic acid, isoflavones, phytosterols and saponins, and their role in the prevention of various chronic diseases.

\section{Non-Nutritive Bioactive Components in Pulses}

The nutritional factors in pulse grains are widely considered critical for human nutrition, however, the overwhelming evidence from epidemiological studies indicate that diets rich in pulse grains are also associated with a lower risk of several degenerative diseases, attributed to the fact that these foods supply several non-nutritive bioactive compounds/health-promoting mixture of phytochemicals which act as natural antioxidants and and protects DNA damage (Table 1).

\subsection{Enzyme Inhibitors}

Protein inhibitors of hydrolases present in pulses are active against proteases, amylases, lipases, glycosidases, and phosphatases. From the nutritional aspect, the inhibitors of the serine proteases trypsin and chymotrypsin are the most important [10]. Common beans (Phaseolus 
Table 1. Major non-nutritive bioactive phytochemicals in pulses.

\begin{tabular}{cll}
\hline Sr. No. & Bioactive components & Potential biological effects/health effects \\
\hline 1 & Protease inhibitors & Reduces digestibility and bioavailability of nutrients \\
2 & Amylase inhibitors & Reduces utilization of dietary starch and protein, Potentially therapeutic in diabetes. \\
& & Can reduce the digestibility and biological value of dietary proteins. \\
& Can impair the integrity of the intestinal epithelium and thus alter the absorption and utilization of nutrients \\
& Lectins & Protective effect on oxidative DNA damage and cancer chemoprevention \\
& & $\begin{array}{l}\text { Decreases mineral bioavailability } \\
\text { Acts as anticarcinogen. }\end{array}$ \\
& Phytates & Antioxidant activity and protects DNA damage \\
5 & Phenolic compounds & Antioxidant activity, Has been inversely associated with the risk of colon cancer \\
6 & Phytosterols & Lowers serum cholesterol level \\
7 & Saponins & A potent calcium-activated potassium channel opener.. \\
\end{tabular}

vulgaris) are the second largest group of seeds after cereals reported as natural sources of $\alpha$-amylase inhibitors [11]. In common beans, lima bean, cowpea, and lentil, protease inhibitors have been characterized as members of the Bowman-Birk family [10,11]. Protease inhibitor content is moderate in kidney bean and cowpea $(8$ and $10.6 \mathrm{~g}$ of trypsin and $9.2 \mathrm{~g}$ of chymotrypsin inhibited $\mathrm{kg}^{-1}$, respectively), and low in lupin seeds (1.1 $\mathrm{g}$ of trypsin and $1.4 \mathrm{~g}$ of chymotrypsin inhibited $\mathrm{kg}^{-1}$ ) [12].

\subsection{Lectins}

Lectins or haemagglutinins are found in most plant foods [13], however, grain legumes are the main sources of lectins in human food. Beans (most species, including Phaseolus vulgaris) seems to be important source of lectins. Lectins from some of the pulses can inhibit the growth of experimental animals and reduce the digestibility and biological value of dietary proteins [14]. These antinutritional effects are most likely caused by some lectins that can impair the integrity of the intestinal epithelium and thus alter the absorption and utilization of nutrients. Lectin can be completely removed from lentil flour after $72 \mathrm{~h}$ fermentation at $42^{\circ} \mathrm{C}$ with a flour concentration of $79 \mathrm{~g} \cdot \mathrm{L}^{-1}$ [15]. High level of lectins has been reported in kidney beans $\left(840 \times 10^{-5}\right.$ hemagglutinating activity units (HU) $\mathrm{kg}^{-1}$ ) and very low amount in cowpea and lupin seeds $\left(3 \times 10^{-5} \mathrm{HU} \cdot \mathrm{kg}^{-1}\right)$ [13]. Studies have suggested that lectins affect the immune response against ovalbumin and may promote the development of food allergy to plants containing lectins. Lectin is one of the major proteins found in lentil (Lens culinaris). It accounts for about $2.4 \%-5 \%$ of the total protein $(17 \%$ $23 \%$ ) in kidney bean seeds, $0.8 \%$ in lima bean protein $(21 \%)$, and around $0.6 \%$ of the total protein $(24 \%-25 \%)$ in garden pea [16].

\subsection{Phytosterols}

In pulses, phytosterols are present in small quantities, and the most common phytosterols are $\beta$-sitosterol, campesterol, and stigmasterol [17]. These compounds are also abundant as sterol glucosides and esterified sterol glucosides, with $\beta$-sitosterol representing $83 \%$ of the glycolipids in defatted chickpea flour [18]. Total phytosterol content detected in the legumes ranged from 134 $\mathrm{mg} / 100 \mathrm{~g}$ (kidney bean) to $242 \mathrm{mg} / 100 \mathrm{~g}$ (pea) [19]. Total $\beta$-sitosterol content ranged from $160 \mathrm{mg} / 100 \mathrm{~g}$ (chickpea) to $85 \mathrm{mg} / 100 \mathrm{~g}$ (butter bean). Chickpea and pea contained high levels of campesterol $(21.4$ and $25.0 \mathrm{mg} / 100 \mathrm{~g}$, respectively). Weihrauch and Gardner [20], reported 127 $\mathrm{mg} / 100 \mathrm{~g}$ phytosterol level for kidney bean, with much lower concentration of phytosterols in chickpea $(35 \mathrm{mg} /$ $100 \mathrm{~g}$ ). The consumption of pulse grains has been reported to lower serum cholesterol and increase the saturation levels of cholesterol in the bile. A dietary study conducted by Duane [21], on humans over a seven week period showed that serum LDL cholesterol was significantly lower during the consumption of a diet consisting of beans, lentil, and field pea. The study showed that consumption of pulses lowers LDL cholesterol by partially interrupting the entrohepatic circulation of the bile acids and increasing the cholesterol saturation by increasing the hepatic secretion of cholesterol. Several studies have demonstrated the efficacy of plant sterols and stanols in the reduction of blood cholesterol levels, and plant sterols are increasingly incorporated into foods for this purpose [22].

\subsection{Phytic Acid}

Phytic acid (myo-inositol hexaphosphate or $\mathrm{InsP}_{6}$ ), is a major phosphorus storage form in plants, and its salts 
known as phytates regulate various cellular functions such as DNA repair, chromatin remodeling, endocytosis, nuclear messenger RNA export and potentially hormone signaling important for plant and seed development [23]. It is often regarded as an antinutrient because of strong mineral, protein and starch binding properties thereby decreasing their bioavailability [24]. Phytate play important role in plant metabolism, stress and pathogen resistance in addition to their beneficial effects in human diets by acting as anticarcinogen [25] or by promoting health in other ways such as in decreasing the risk of heart disease or diabetes [26]. Pulses have high content of phytate, which is located in the protein bodies in the endosperm. Raw lentil contained $0.3 \mathrm{mmol} \cdot \mathrm{kg}^{-1}$ of $\operatorname{Ins}_{3}$ [27]. The most abundant inositol phosphate in raw, dry legume is InsP $\mathrm{P}_{6}$, accounting for an average of $83 \%$ of the total inositol phosphates, ranging from $77 \%$ in chickpea to $88 \%$ in black bean [28]. The InsP ${ }_{6}$ concentration tends to be higher in raw dry bean, blackeye pea, and pigeon pea than in lentil, green and yellow split pea, and chickpea and ranged between 14.2 and $6 \mathrm{mmol} \cdot \mathrm{kg}^{-1}$ in black bean and chickpea, respectively [28]. In vivo and in vitro studies have demonstrated that inositol hexaphosphate InsP $_{6}$, phytic acid) exhibits significant anticancer (preventive as well as therapeutic) properties [29]. The anticarcinogenic properties of phytic acid may result from numerous factors. The backbone of most inositol phosphates in cells is myo-inositol. Myo-inositol and Ins $\mathrm{P}_{6}$ have synergistic or additive effects in inhibiting the development of cancer [30]. In mice, dietary myoinositol has been shown to be effective in preventing cancer of the lung [30], fore stomach [30], and liver [30,31].

\subsection{Phenolic Compounds}

Phenolic compounds are one of the biggest groups of nonessential dietary compounds. The bioactivity of phenols is attributed to their ability to chelate metals, inhibit lipid peroxidation and scavenge free radicals [32]. According to Rice-Evans et al. [33], the antioxidant properties of phenolics occur mainly due to their potential for ox-reduction, which enables them to act as reducing agents, donating hydrogen and neutralizing free radicals. The major phenolic compounds of pulses consist mainly of tannins, phenolic acids and flavonoids. The seed color of pulses is mainly due to the presence of polyphenolic compounds viz., flavonoids such as flavonol glycosides, anthocyanins, and condensed tannins (proanthocyanidins) [34]. The pulses with the highest polyphenolic content are dark, highly pigmented varieties, such as red kidney beans (Phaseolus vulgaris) and black gram (Vigna mungo) [35]. Lentil has the highest phenolic, flavonoid and condensed tannin content $(6.56 \mathrm{mg}$ gallic acid equivalents $\mathrm{g}^{-1}, 1.30$ and $5.97 \mathrm{mg}$ catechin equivalents $\mathrm{g}^{-1}$, respectively), followed by red kidney and black beans [35].
Lentil showed a high Total Antioxidant Capacity (TAC) probably related to the high content of condensed tannins present in lentil [36]. The seed coat in lentil is very rich in catechins, procyanidins dimers and trimers. It was reported that the major monomeric flavan-3-ol was $(+)$ catechin-3glucose, with lesser amounts of $(+)$-catechin and (-)-epicatechin [37]. Until recently, phenolic compounds were regarded as non-nutritive com- pounds and it was reported that excessive content of polyphenols, in particular tannins, may have adverse consequences because it inhibits the bioavailability of iron and blocks digestive enzymes in the gastrointestinal tract [35]. Phenolic compounds can also limit the bioavailability of proteins with which they form insoluble complexes in the gastrointestinal tract. Later on, the significance of phenolic compounds was gradually recognized and several researches have now reported that phenolics offer many health benefits and are vital in human nutrition [36]. High correlations between phenolic compositions and antioxidant activities have been reported [37]. Pulses with highest total phenolic content (lentil, red kidney and black bean) exert the highest antioxidant capacity assessed by 2,2-diphenyl-1-picryhydrazyl (DPPH) free radical scavenging, ferric reducing antioxidant power (FRAP), and the oxygen radical absorbance capacity (ORAC) [38]. Chickpea contains a wide range of polyphenolic compounds, including flavonols, flavone glycosides, flavonols, and oligomeric and polymeric proanthocyanidins. Total phenolic content in chickpea ranges from 0.92 to $1.68 \mathrm{mg}$ gallic acid equivalents $\mathrm{g}^{-1}$ [39]. Xu and Chang [38], investigated the chemical and cellular antioxidant activities and phenolic profiles of 11 lentil cultivars and found that five phenolic acids of the benzoic types and their derivates (gallic, protocatechuic, 2,3,4-trihydroxybenzoic, $p$-hydroxybenzoic acid, and protocatechualdehyde) and four phenolic acids of the cinnamic type (chlorogenic, $p$-coumaric, $m$-coumaric, and sinapic acid) as well as two flavan-3-ols $[(+)$-catechin and (-)-epicatechin] and one flavone (luteolin) were detected in all lentil cultivars. Among all phenolic compounds detected, sinapic acid was the predominant phenolic acid, and $(+)$-catechin and (-)-epicatechin were the predominant flavonoids. Tsopmo and Muir [37]) studied the chemical profile of lentil (Lens culinaris Medik.) cultivars. Chromatographic separations of the methanol extract afforded several compounds including the novel 4-chloro- $1 \mathrm{H}$-indole-3- $\mathrm{N}$ methylacetamide as well as itaconic acid, arbutin, gentisic acid 5- $O-[\beta$-D-apiofuranosyl- $(1 \rightarrow 2)-\beta$-D-xylopyranoside], and $(6 S, 7 Z, 9 R)$-9-hydroxy-megastigma-4,7-dien-3one-9-O- $\beta$-D-apiofuranosyl-( $1 \rightarrow 2)-\beta$-D-gluco-pyranoside.

\subsection{Isoflavones}

Isoflavones are largely reported from the Fabaceae/Leguminosae family. According to the USDA survey, lentil 
does not contain significant amounts of these isoflavones [40]. Chickpea contains daidzein, genistein, and formononetin $(0.04,0.06$, and $0.14 \mathrm{mg} / 100 \mathrm{~g}$, respectively), and approximately $1.7 \mathrm{mg} / 100 \mathrm{~g}$ biochanin A [40]. Soybean has significantly higher levels of daidzein and genistein (47 and $74 \mathrm{mg} / 100 \mathrm{~g}$, respectively) but contain less formononetin and biochanin $\mathrm{A}$ as compared to chickpea. There are many biological activities associated with the isoflavones, including a reduction in osteoporosis, cardiovascular disease and prevention of cancer and for the treatment of menopause symptoms [41].

\subsection{Saponins}

Saponins are composed of a lipid-soluble aglycon consisting of either a sterol or more commonly a triterpenoid and water soluble sugar residues differing in type and amount of sugars. Saponins lower nutrient availability [42] and decrease enzyme activity [43] contributing to a growth-retarding effect in animals [44]. There is enormous structural diversity within this chemical class, and only a few are toxic [9]. There is renewed interest in these biologically active plant components because recent evidence suggests that saponins possess hypocholesterolemic [44], anti-carcinogenic [45] and immune-stimulatory properties [46]. Soybean and chickpea constitute major sources of saponins in the human diet [47]. Saponins have been reported in many pulses, lupin [48], lentil [49], and chickpea [50], as well various beans, and pea [9]. Chickpea, black gram, moth bean, broad beans and peas can contain $3.6,2.3,3.4,3.7$, and $2.5 \mathrm{~g} \cdot \mathrm{kg}^{-1}$ dry matter of saponins, respectively [50]. Saponin content in dehulled light and dark colored peas ranges from 1.2 to $2.3 \mathrm{~g} \cdot \mathrm{kg}^{-1}$ dry matter [51]. Some saponin is lost during processing as has been reported in moth bean [52], black gram [53] and pigeon pea [54].

\section{Antioxidant Phytochemicals in Pulse Grains}

In the past few years, the antioxidant properties of food has been extensively studied since excessive production of free radicals/reactive oxygen species (ROS) and lipid peroxidation are widely believed to be involved in the pathogenesis of many diseases such as cardiovascular diseases, cancers, autoimmune disorders, rheumatoid arthritis, various respiratory diseases, cataract, Parkinson's or Alzhemier's diseases and also ageing. Evidence further suggests that plant derived antioxidants such as flavonoids, and related phenolic compounds plays a crucial role in the prevention of these chronic diseases [36]. Beninger and Hosfield [55], showed that pure flavonoid compounds such as anthocyanins, quercetin glycosides and protoanthocyanidins (condensed tanins), present in the seed coat methanol extract and tannin fractions from
10 colored genotypes of common bean Phaseolus vulgaris, all displayed antioxidant activity, while the highest activity was obtained with extracts rich in condensed tannins. The total antioxidant capacity (TAC) value for chickpea was reported as $10.7 \pm 1.3 \mathrm{mmol}$ Trolox $/ \mathrm{kg}[56] . \mathrm{Xu}$ and Chang, [57] reported that caffeic acid, catechin, epicatechin, and total flavonoids significantly $(p<0.05)$ correlated with peroxyl radical scavenging assay in lentil cultivars. Sreeramulu et al [58], evaluated the antioxidant activity of pulses, commonly consumed in India and assessed the relationship with their total phenolic content. The total phenolic content (TPC) in pulses ranged from 62.35 to $418.34 \mathrm{mg} / 100 \mathrm{~g}$. The black gram dhal had highest TPC (418.34 mg/100g), while green gram dhal had the least $(62.35 \mathrm{mg} / 100 \mathrm{~g})$. In the same study [58], the antioxidant activity as determined by three different methods showed a wide range of values viz., DPPH radical scavenging activity (1.07 TE/g), FRAP (373 umol/g) and reducing power $(4.89 \mathrm{mg} / \mathrm{g})$, all three were highest in Rajmash. Sreeramulu et al. [58] further showed that in pulses the total phenolics content (TPC) was poorly correlated with antioxidant activity (AOA), suggesting thereby that TPC might not contribute significantly to the AOA in pulses.

\section{Effect of Processing of Pulse Grains on Antioxidant Activity}

The Antioxidant activity from foods can be influenced by the methods applied for its consumption. Various steps of processing result in significant decrease in total phenolic content (TPC) and DPPH free radical scavenging activity (DPPH) [57]. The same study also revealed that soaking and atmospheric boiling treatments decreased, while pressure boiling and steaming increased the oxygen radical absorbing capacity (ORAC). Steaming treatments resulted in a greater retention of TPC, DPPH, and ORAC values as compared to boiling treatments. However, TPC and DPPH in cooked lentil differed significantly between atmospheric and pressure boiling. Pressure processes significantly increased ORAC values in both boiled and steamed pulses compared to atmospheric processes. Greater TPC, DPPH, and ORAC values were detected in boiling water than in soaking and steaming water. Steam processing exhibited several advantages in retaining the integrity of the legume appearance and texture of the cooked product, shortening process time, and greater retention of antioxidant components. Segev et al. [39], studied the total phenolic content and antioxidant activity of chickpea (Cicer arietinum L.) as affected by soaking and cooking and reported that chickpea lines with colored testa (seed coat) contain high levels of polyphenolic compounds that exhibit high levels of antioxidant activity. They further re- ported that common processing procedures, such as soak- ing and cooking, may decrease 
the level of these bioactive compounds and subsequent overall antioxidant activity. Here, the effects of soaking, cooking and steaming processes were examined in relation to total phenolic content (TPC), total flavonoid content (TFC) and ferric reducing ability of plasma antioxidant activity (FRAP AA) of colored chickpea seeds. All processing steps significantly reduced TPC, TFC and FRAP AA in all of the tested chickpea seeds. Nevertheless, soaking the seeds at room temperature (for $22 \mathrm{~h}$ ) resulted in a smaller decrease in TPC, TFC and FRAP AA than soaking at $60^{\circ} \mathrm{C}$ (for $2 \mathrm{~h}$ ). Moreover, steaming was superior to cooking in terms of conserving polyphenol and antioxidant activity. Based on these results, it was suggested that soaking at room temperature for $22 \mathrm{~h}$ followed by steaming for $1 \mathrm{~h}$ is the best method for retaining TPC, TFC and FRAP AA of colored chickpea.

\section{Pulses and Human Health}

The consumption of pulse grains has been reported to lower serum cholesterol and increase the saturation levels of cholesterol in the bile. Total serum cholesterol was reduced by $7 \%$, LDL cholesterol by $6 \%$ and serum triacylglycerols by more than $17 \%$, with no significant change in HDL-cholesterol [3]. Legume consumption of four times or more per week compared with less than once a week, was associated with $22 \%$ lower risk of CHD, and $11 \%$ lower risk of CVD [59]. Further the replacement of refined rice with whole grain and legume powder as a source of carbohydrate in a meal showed significant beneficial effects on glucose, insulin, and homocysteine concentrations and lipid peroxidation in coronary artery disease (CAD) patients, these effects are likely to substantially reduce the risk factors for CAD and diabetes [60]. The effect was primarily attributed to the content of soluble dietary fibre which has been shown to reduce total and low-density lipoprotein, cholesterol levels, as well as insulin resistance [61]. Among the food legumes, chickpea is the most hypocholesteremic agent. Dietary supplementation with chickpea resulted in significant reductions in serum total and low-density lipoprotein cholesterols in adult woman and men [62]. A recently published meta-analysis concluded that a higher intake of folate $(0.8 \mathrm{mg}$ folic acid) would reduce the risk of ischaemic heart disease by $16 \%$ and stroke by $24 \%$ [63]. The B-vitamin, folate has been shown to reduce homocysteine concentration, where elevated homocysteine levels have been identified as significant risk factor for increased risk of cardiovascular diseases [64]. Pea, chickpea and mungbean protein hyrolysates have been shown to have angiotensin converting enzyme (ACE) inhibitory activity [65]. Since ACE plays a key role in modulating blood pressure, ACE inhibitors, including those derived from pulses, may improve cardiovascular health [65].
Pulses are low glycemic index (GI) foods with GI values ranging from 28 - 52 [66]. The low GI in pulses is due to abundance of non-starch polysaccharides, resistant starch and oligosaccharides [67]. A decrease of blood glucose response has also been attributed to phytic acid, lectins, amylase inhibitors, or polyphenol compounds in pulse seeds [68]. A substantial increase in dietary intake of pulses as replacement food for more rapidly digested carbohydrate might therefore be expected to improve glycemic control and thus reduce incident diabetes [69]. Jenkins et al. [70] have shown that low GI diets resulted in moderately reduced level of Hemoglobin $(\mathrm{Hb}) \mathrm{A}_{1 \mathrm{c}}$ (a glycosylated protein) which is an indicator of glucose level in blood. Further a meta-analysis of 11 studies has revealed that low GI diets resulted in decrease in mean blood glucose levels, a decrease in $\mathrm{HbA}_{1 \mathrm{c}}$ and improved plasma lipid parameters compared with high GI diets [71]. Recently Villegas et al., [72] reported that adherence to vegetables and pulses were inversely associated with the risk of type 2 diabetes in a large Chinese population. Subjects consuming fibre-rich beans, and legumes, had the lowest BMI, smallest waist circumference (WC), and the smallest mean annual increase in BMI and improved satiety [73]. The low-GI diet (high in wholegrain bread and beans and with less white bread and rice) resulted in improved glycemic control and greater weight loss [74].

Inverse correlations between pulse consumption and colon cancer mortality and risks of prostrate cancer, gastric cancer and pancreatic cancer have been reported in several epidemiological studies [75]. Adebamowo et al. [76] reported that bean or lentil intake is associated with a lower risk of breast cancer. Pulses are excellent source of B-vitamin folate [77], which may play a protective role against colorectal, cervical, breast and pharyngeal cancers [78]. Selenium, primarily due to its potent antioxidant effect, appears to have a protective effect against colorectal, prostrate and lung cancers [79]. Pulses are major source of saponins, which also have antioxidant effect, exhibits direct and selective cytotoxic action against cancer cells [80]. Pea protease inhibitors also show promise as cancer chemoprventive agents [81]. The non-digestible carbohydrate in pulses (insoluble dietary fiber, oligosaccharides, resistant starch) [82] stimulates growth and/or activity of bacteria such as bifidobacteria and lactobacilli in the colon, resulting in increased formation of butyrate, a short chain fatty acid with demonstrated anti-tumor and anti-inflammatory activity [83]. In addition, pulses, particularly common bean, contain a number of polyphenols, with antioxidant and anti-mutagenic activities that could inhibit the formation of tumors [55]. In a large prospective cohort study a reduced breast cancer risk was associated with higher intake of pulses [84]. Other studies revealed that consumption of pulses 
such as dried beans, split peas, or lentils was negatively associated with risk of colorectal adenoma [85].

\section{Conclusion}

Pulses make a major share of the human diet in many locations of the world and play a significant role in the human nutrition, especially as source of protein, vitamins, minerals, dietary fibre and folic acid. Besides these important nutrients, the pulse grains also contain certain biologically active components including enzyme inhibitors, lectins, phytates, oligosaccharides, and phenolic compounds. Some of these substances have been considered as antinutritional factors due to their effect on diet quality. On the other hand, these same compounds may have protective effects. Important biological activities have now been suggested for these bioactive compounds like enhancement of the antioxidant, antimutagenic, anticarcinogenic and antihyperglycemic effects, which makes pulses an important crop for human health.

\section{REFERENCES}

[1] J. W. Anderson, T. J. Hanna, X. Peng and R. J. Kryscio, "Whole Grain Foods and Heart Disease Risk," Journal of the American College of Nutrition, Vol. 19, No. 3, 2000, pp. 291S-299S.

[2] C. A. Patterson, H. Maskus and C. Dupasquier, "Pulse Crops for Health," Cereals Foods World, Vol. 54, No. 3, 2009, pp. 108-112.

[3] J. W. Anderson and A. W. Major, "Pulses and Lipaemia, Short and Long Term Effect: Potential in the Prevention of Cardiovascular Disease," British Journal of Nutrition, Vol. 88, No. 3, 2002, pp. S263-S271. doi:10.1079/BJN2002716

[4] M. M. Champ, "Non-Nutrient Bioactive Substances of Pulses," British Journal of Nutrition, Vol. 88, No. 3, 2002, pp. S307-S319. doi:10.1079/BJN2002721

[5] K. T. Chung, T. Y. Wong, C. I. Wei, Y. W. Huang and Y. Lin, "Tannins and Human Health: A Review," Critical Reviews in Food Science and Nutrition, Vol. 38, No. 6, 1998, pp 421-464. doi:10.1080/10408699891274273

[6] J. C. Mathers, "Pulses and Carcinogenesis: Potential for Prevention of Colon, Breast and Other Cancers," British Journal of Nutrition, Vol. 88, No. 3, 2002, pp. 272-279. doi:10.1079/BJN2002717

[7] B. Q. Phillippy, "Inositol Phosphates in Food," Advances in Food and Nutrition Research, Vol. 45, 2003, pp. 1-60. doi:10.1016/S1043-4526(03)45002-X

[8] C. T. Yeh and G. C. Yen, "Effects of Phenolic Acids on Human Phenol Sulfo-Transferases in Relation to Their Antioxidant Activity," Journal of Agricultural and Food Chemistry, Vol. 51, No. 5, 2003, pp. 1474-1479. doi:10.1021/jf0208132

[9] J. Shi, K. Arunasalam, D. Yeung, Y. Kakuda, G. Mittal and Y. Jiang, "Saponins from Edible Legumes: Chemistry, Processing, and Health Benefits," Journal of Medicinal
Food, Vol. 7, No. 1, 2004, pp 67-78. doi: $10.1089 / 109662004322984734$

[10] H. D. Belitz and J. K. P. Weder, "Protein Inhibitors of Hydrolases in Plants Foodstuffs," Food Reviews International, Vol. 6, No. 2, 1990, pp. 151-211. doi:10.1080/87559129009540866

[11] F. M. Lajolo, F. Finardi-Filho and E. W. Menezes, “Amylase Inhibitors in Phaseolus vulgaris Beans," Food Technology, Vol. 45, No. 9, 1991, pp. 119-121.

[12] G. Grant, P. M. Dorward, W. C. Buchan, J. C. Armour and A. Pusztai, "Consumption of Diets Containing Soya Beans (Glycine max), Kidney Beans (Phaseolus vulgaris), Cowpeas (Vigna unguiculata) or Lupin Seeds (Lupinus augustifolius) by Rats for up to 700 Days: Effects on Body Composition and Organ Weights," British Journal of Nutrition, Vol. 73, No. 1, 1995, pp. 17-29. doi:10.1079/BJN19950005

[13] M. S. Nachbar and J. D. Oppenheim, "Lectins in the United States Diet. A Survey of Lectins in Commonly Consumed Foods and a Review of the Literature," American Journal of Clinical Nutrition, Vol. 33, No. 11, 1980, pp. 2338-2345.

[14] A. Pusztai, G. Grant, T. Duguid, D. S. Brown, W. J. Peumans, Van E. J. Damme, et al., "Inhibition of Starch Digestion by $\alpha$-Amylase Inhibitor Reduces the Efficiency of Utilization of Dietary Proteins and Lipids and Retards the Growth of Rats," Journal of Nutrition, Vol. 125, No. 6, 1995, pp. 1554-1562.

[15] C. G. Cuadrado, C. Hajos, M. M. Burbano, G. Ayet Pedrosa and M. Muzquiz, et al., "Effect of Natural Fermentation on the Lectin of Lentils Measured by Immunological Methods," Food and Agricultural Immunology, Vol. 14, No. 1, 2002, pp. 41-49. doi:10.1080/09540100220137655

[16] J. Zhang, J. Shi, S. Ilic, X. S. Jun and Y. Kakuda, "Biological Properties and Characterization of Lectin from Red Kidney Bean (Phaseolus vulgaris)," Food Reviews International, Vol. 25, No. 1, 2009, pp. 12-27. doi:10.1080/87559120802458115

[17] P. Benveniste, "Sterol Biosynthesis," Annual Review of Plant Physiology, Vol. 37, No. 1, 1986, pp. 275-308. doi:10.1146/annurev.pp..37.060186.001423

[18] R. Sanchez-Vioque, A. Clemente, J. Vioque, J. Bautista and F. Millan, "Polar Lipids of Defatted Chickpea (Cicer arietinum L.) Flour and Protein Isolates," Food Chemistry, Vol. 63, No. 3, 1998, pp. 357-361. doi:10.1016/S0308-8146(98)00015-6

[19] E. Ryan, K. Galvin, T. P. O'Connor, A. R. Maguire and N. M. O'Brien, "Phytosterol, Squalene, Tocopherol Content and Fatty Acid Profile of Selected Seeds, Grains, and Legumes," Plant Foods for Human Nutrition, Vol. 62, No. 3, 2007, pp. 85-91. doi:10.1007/s11130-007-0046-8

[20] J. L. Weihrauch and J. M. Gardner, "Sterol Content of Foods of Plant Origin," Journal of the American Dietetic Association, Vol. 73, 1978, pp. 39-44.

[21] W. C. Duane, "Effects of Legume Consumption on Serum Cholesterol, Biliary Lipids, and Sterol Metabolism in Humans," Journal of Lipid Research, Vol. 38, No. 6, 
1997, pp. 1120-1128.

[22] H. Gylling and T. A. Miettinen, "The Effect of Plant Stanol- and Sterol-Enriched Foods on Lipid Metabolism, Serum Lipids and Coronary Heart Disease," Annals of Clinical Biochemistry, Vol. 42, No. 4, 2005, pp. 254-263. doi:10.1258/0004563054255605

[23] J. R. Zhou and J. W. Erdman Jr., "Phytic Acid in Health and Disease," Critical Reviews in Food Science and Nutrition, Vol. 35, No. 6, 1995, pp. 495-508. doi:10.1080/10408399509527712

[24] C. M. Weaver and S. Kannan, "Phytate and Mineral Bioavailability," In: N. R. Sathe and S. K. Reddy, Eds., Food Phytates, CRC, Boca Raton, 2002, pp. 211-224.

[25] I. Vucenik and A. M. Shamsuddin, "Protection against Cancer by Dietary IP6 and Inositol," Nutrition and Cancer, Vol. 55, No. 2, 2006, pp. 109-125. doi:10.1207/s15327914nc5502_1

[26] A. N. Minihane and G. Rimbach, "Iron Absorption and the Iron Binding and Anti-Oxidant Properties of Phytic acid," International Journal of Food Science and Technology, Vol. 37, No. 7, 2002, pp. 741-748. doi:10.1046/j.1365-2621.2002.00619.x

[27] E. R. Morris and A. D. Hill, "Inositol Phosphate Content of Selected Dry Beans, Peas, and Lentils, Raw and Cooked," Journal of Food Composition and Analysis, Vol. 9, No. 1, 1996, pp. 2-12. doi:10.1006/jfca.1996.0002

[28] A. M. Shamsuddin, "Metabolism and Cellular Functions of IP6: A Review," Anticancer Research, Vol. 19, No. 5A, 1999, pp. 3733-3736.

[29] A. M. Shamsuddin, "Anti-Cancer Function of Phytic Acid," International Journal of Food Science and Technology, Vol. 37, No. 7, 2002, pp. 769-782. doi:10.1046/j.1365-2621.2002.00620.x

[30] R. D. Estensen and L. W. Wattenberg, "Studies of Chemopreventive Effects of Myo-Inositol on Benzo[a]pyrene-Induced Neoplasia of the Lung and Fore Stomach of Female A/J Mice," Carcinogenesis, Vol. 14, No. 9, 1993, pp. 1975-1977. doi:10.1093/carcin/14.9.1975

[31] H. Nishino, M. Murakoshi, M. Masuda, H. Tokuda, Y. Satomi and M. Onozuka, et al., "Suppression of Lung and Liver Carcinogenesis in Mice by Oral Administration of Myo-Inositol," Anticancer Research, Vol. 19, No. 5A, 1999, pp. 3663-3664.

[32] L. M. Cheung, P. C. K Cheung and V. E. C. Ooi, “Antioxidant Activity and Total Phenolics of Edible Mushroom Extracts," Food Chemistry, Vol. 80, No. 2, 2003, pp. 249255. doi:10.1016/S0308-8146(02)00419-3

[33] C. A. Rice-Evans, N. J. Miller and G. Paganga, "Antioxidant Properties of Phenolic Compounds," Trends Plant Science, Vol. 2, No. 4, 1997, pp. 152-159. doi:10.1016/S1360-1385(97)01018-2

[34] M. Duenas, B. Sun, T. Hernandez, I. Estrella and M. I. Spranger, "Proanthocyanidin Composition in the Seed Coat of Lentils (Lens culinaris L.)," Journal Agriculture Food Chemistry, Vol. 51, No. 27, 2003, pp. 7999-8004. doi:10.1021/jf0303215

[35] P. K. South and D. D. Miller, "Iron Binding by Tannic Acid; Effects of Selected Ligands," Food Chemistry, Vol.
63, No. 2, 1998, pp. 167-172. doi:10.1016/S0308-8146(98)00040-5

[36] B. J. Xu and S. K. C. Chang, "Phenolic Substance Characterization and Chemical and Cell-Based Antioxidant Activities of 11 Lentils Grown in the Northern United States," Journal of Agricultural and Food Chemistry, Vol. 58, No. 3, 2010, pp. 1509-1517. doi:10.1021/jf903532y

[37] T. Apollinaire and A. D. Muir, "Chemical Profiling of Lentil (Lens culinaris Medik.) Cultivars and Isolation of Compounds," Journal Agriculture Food Chemistry, Vol 58, No. 15, 2010, pp. 8715-8721. doi:10.1021/jf101412y

[38] B. J. Xu and S. K. C. Chang, "A Comparative Study on Phenolic Profiles and Antioxidant Activities of Legumes as Affected by Extraction Solvents," Journal of Food Science, Vol. 72, No. 2, 2007, pp. S159-S166. doi:10.1111/j.1750-3841.2006.00260.x

[39] A. Segev, H. Badani, L. Galili, R. Hovav, Y. Kapulnik, I. Shomer and S. Galili, "Total Phenolic Content and Antioxidant Activity of Chickpea (Cicer arietinum L.) as Affected by Soaking and Cooking Conditions," Food and Nutrition Science, Vol. 2, No. 7, 2011, pp. 724-730. doi:10.4236/fns.2011.27099

[40] USDA, "USDA-Iowa State University Database on the Isoflavone Content of Foods," Agricultural Research Service, US Department of Agriculture, Washington, 2002.

[41] A. Cassidy, P. Albertazzi, I. Lise Nielsen, W. Hall, G. Williamson, I. Tetens, et al., "Critical Review of Health Effects of Soyabean Phyto-Oestrogens in Post-Menopausal Women," The Proceedings of the Nutrition Society, Vol. 65, No. 1, 2006, pp. 76-92. doi:10.1079/PNS2005476

[42] L. G. West and J. L. Greger, "In Vitro Studies on Saponin Vitamin Complexation," Journal Food Science, Vol. 43, No. 4, 1978, pp. 1340-1341. doi:10.1111/j.1365-2621.1978.tb15308.x

[43] P. R. Cheek and J. E. Oldfield, "In Vitro Inhibition of Succinate Oxidation by Alfalfa Saponin," Canadian Journal Animal Sciences, Vol. 50, No. 1, 1970, pp. 107-112. doi:10.4141/cjas70-013

[44] P. R. Cheek, "Nutritional and Physiological Implications of Saponins: A Review," Canadian Journal Animal Sciences, Vol. 51, No. 3, 1971, pp. 621-632. doi:10.4141/cjas71-082

[45] H. Tokuda, T. Konoshima, M. Kozuka and T. Kimura, "Inhibition of 12-o-tetradecanoylphorbol-13-Acetate-Promoted Mouse Skin Papilloma Saponins," Oncology, Vol. 48, No. 1, 1991, pp. 77-80. doi:10.1159/000226899

[46] R. T. Wu, H. C. Chiang, W. C. Fu, K. Y. Chien, Y. M. Chung and L. Y. Horng, "Formosanin-C, an Immunomodulator with Antitumor Activity," International Journal Immunopharmacology, Vol. 12, No. 7, 1990, pp. $777-$ 786. doi:10.1016/0192-0561(90)90042-L

[47] D. Oakenfull, "Saponins in Food-A Review," Food Chemistry, Vol. 7, No. 1, 1981, pp. 19-40. doi:10.1016/0308-8146(81)90019-4

[48] G. M. Woldemichael, G. Montenegro and B. N. Timmermann, "Triterpenoidal Lupin Saponins from the Chilean Legume Lupinus oreophilus Phil.," Phytochemistry, Vol. 
63, No. 8, 2003, pp. 853-857. doi:10.1016/S0031-9422(03)00328-5

[49] R. G. Ruiz, K. R. Price, A. E. Arthur, M. E. Rose, M. J. C. Rhodes and R. G. Fenwick, "Effect of Soaking and Cooking on the Saponin Content and Composition of Chickpeas (Cicer arietinum) and Lentils (Lens culinaris)," Journal of Agricultural and Food Chemistry, Vol. 44, No. 6, 1996, pp. 1526-1530. doi:10.1021/jf950721v

[50] T. A. El-Adawy, "Nutritional Composition and Antinutritional Factors of Chickpeas (Cicer arietinum L.) Undergoing Different Cooking Methods and Germination," Plant Foods for Human Nutrition, Vol. 57, No. 1, 2002, pp. 83-97. doi:10.1023/A:1013189620528

[51] Y. D. A. P. Daveby, J. M. Betz and S. M. Musser, "Effect of Storage and Extraction on Ratio of Soyasaponin I to 2,3-Dihydro-2,5-dihydroxy-6-methyl-4-pyrone-Conjugated Soyasaponin I in De-Hulled Peas (Pisum sativum L.)," Journal of the Science of Food and Agriculture, Vol. 78, No. 1, 1998, pp. 141-146.

doi:10.1002/(SICI)1097-0010(199809)78:1<141::AID-JS FA169>3.0.CO;2-6

[52] S. Khokhar and B. M. Chauhan, "Antinutritional Factors in Moth Bean: Varietal Differences and Effects of Methods of Domestic Processing and Cooking," Journal of Food Science, Vol. 51, No. 3, 1986, pp. 591-594. doi:10.1111/j.1365-2621.1986.tb13887.x

[53] A. Kataria, B. M. Chauhan and D. Punia, "Anti-Nutrients in Amphidiploids (Black Gram $\times$ Mung Bean): Varietal Differences and Effect of Domestic Processing and Cooking," Plant Foods for Human Nutrition, Vol. 39, No. 3, 1989, pp. 257-266. doi:10.1007/BF01091936

[54] A. Duhan, N. Khetarpaul and S. Bishnoi, "Saponin Content and Trypsin Inhibitor Activity in Processed and Cooked Pigeon Pea Cultivars," International Journal of Food Science and Nutrition, Vol. 52, No. 1, 2001, pp. 53-59. doi:10.1080/09637480020027200

[55] C. W. Beninger and G. L. Hosfield, "Antioxidant Activity of Extracts, Tannin Fractions, and Pure Flavonoids from Phaseolus vulgaris L," Journal of Agriculture and Food Chemistry, Vol. 51, No. 27, 2003, pp. 7879-7883. doi:10.1021/jf0304324

[56] C. Özge Açar, V. Gökmen, N. Pellegrini and V. Fogliano, "Direct Evaluation of the Total Antioxidant Capacity of Raw and Roasted Pulses, Nuts and Seeds," European Food Research Technology, Vol. 229, No. 6, 2009, pp. 961-969. doi:10.1007/s00217-009-1131-z

[57] B. S. Xu and K. C. Chang, "Effect of Soaking, Boiling, and Steaming on Total Phenolic Content and Antioxidant Activities of Cool Season Food Legumes," Food Chemistry, Vol. 110, No. 1, 2008, pp. 1-13. doi:10.1016/j.foodchem.2008.01.045

[58] D. Sreeramulu, C. V. K. Reddy and M. Raghunath, "Antioxidant Activity of Commonly Consumed Cereals, Millets, Pulses and Legumes in India," Indian Journal of Biochemistry and Biophysics, Vol. 46, No. 1, 2009, pp. 112115. doi:10.1001/archinte.161.21.2573

[59] L. H. J. Bazzano, L. G. Ogden, C. Loria, S. Vupputuri, L. Myers and P. K. Whelton, "Legume Consumption and
Risk of Coronary Heart Disease in US Men and Women: NHANES I Epidemiologic Follow-Up Study," Archives of Internal Medicine, Vol. 161, No. 31, 2001, pp. 2573 2578.

[60] Y. Jang, J. H. Lee, O. Y. Kim, H. Y. Park and S. Y. Lee, "Consumption of Whole Grain and Legume Powder Reduces Insulin Demand, Lipid Peroxidation, and Plasma Homocysteine Concentrations in Patients with Coronary Artery Disease: Randomized Controlled Clinical Trial, Arteriosclerosis," Thrombosis and Vascular Biology, Vol. 21, 2001, pp. 2065-2071. doi:10.1161/hq1201.100258

[61] S. R. Glore, D. Van Treeck, A. W. Knehans and M. Guild, "Soluble Fiber and Serum Lipids: A Literature Review," Journal of the American Dietetic Association, Vol. 94, No. 4, 1994, pp. 425-436. doi:10.1016/0002-8223(94)90099-X

[62] J. K Pittaway, K. D. K. Ahuja, M. Cehun, A. Chronopoulos, I. K. Robertson, P. J. Nestel, et al., "Dietary Supplementation with Chickpeas for at Least 5 Weeks Results in Small but Significant Reductions in Serum Total and Low-Density Lipoprotein Cholesterols in Adult Woman and Men," Annals of Nutrition and Metabolism, Vol. 50, No. 6, 2006, pp. 512-518. doi:10.1159/000098143

[63] D. S. Wald, M. Law and J. K. Morris, "Homocysteine and Cardiovascular Disease: Evidence on Causality from a Meta-Analysis," British Medical Journal, Vol. 325, 2002, pp. 1202-1208. doi:10.1136/bmj.325.7374.1202

[64] C. J. Boushey, S. A. Beresford, G. S. Omenn and A. G. Motulsky, "A Quantitative Assessment of Plasma Homocysteine as a Risk Factor for Vascular Disease," Journal of American Medical Association, Vol. 274, No. 13, 1995, pp. 1049-1057. doi:10.1001/jama.1995.03530130055028

[65] J. Pedrosche, M. M. Yust, J. Giron-Callon, M. Alaiz and F. Milan, "Utilization of Chickpea Protein Hydrolyzates for Production of Peptides with Angiotension I Converting Enzyme (ACE)-Inhibitory Activity," Journal of Science Food and Agriculture, Vol. 82, No. 9, 2002, pp. 960-965. doi:10.1002/jsfa.1126

[66] F. S. Atkinson, K. Foster-Powell and J. C. Brand-Miller, "International Tables of Glycemic Index and Glycemic Load Values," Diabetes Care, Vol. 31, No. 12, 2008, pp. 2281-2283. doi:10.2337/dc08-1239

[67] M. J. Messina, "Legumes and Soyabeans: Overview of Their Nutritional Profiles and Health Effects," American Journal of Clinical Nutrition, Vol. 70, No. 3, 1999, pp. 439S-450S.

[68] S. W. Rizkalla, F. Bellisle and G. Slam, "Health Benefits of Low Glycaemic Index Foods, Such as Pulses, in Diabetic Patients and Healthy Individuals," British Journal of Nutrition, Vol. 88, No. 3, 2002, pp. S255-S262. doi:10.1079/BJN2002715

[69] B. J. Venn and J. I. Mann, "Cereal Grains, Legumes and Diabetes," European Journal of Clinical Nutrition, Vol. 58, No. 11, 2004, pp. 1443-1461. doi:10.1038/sj.ejcn.1601995

[70] D. J. A. Jenkins, C. W. C. Kendall, G. McKeown-Eyssen, R. G. Josse and J. Silverberg, "Effect of Low Glycemic Index or a High Fibre Diet on Type 2 Diabetes," Journal 
American Medical Association, Vol. 300, No. 23, 2008, pp. 2742-2753. doi:10.1001/jama.2008.808

[71] J. C. Brand-Miller, "Importance of Glycemic Index in Diabetes," American Journal Clinical Nutrition, Vol. 59, No. 3, 1994, pp. 747S-752S.

[72] R. Villegas, Y. T. Gao, G. Yang, H. L. Li, T. A. Elasy, W. Zheng, et al., "Legume and Soy Food Intake and the Incidence of Type 2 Diabetes in the Shanghai Women's Health Study," American Journal of Clinical Nutrition, Vol. 87, No. 1, 2008, pp. 162-167.

[73] Y. Papanikolaou and V. L. Fulgoni, "Bean Consumption Is Associated with Greater Nutrient Intake, Reduced Systolic Blood Pressure, Lower Body Weight, and Smaller Waist Circumference in Adults Results from the National Health and Nutrition Examination Survey 1999-2002," Journal of the American College of Nutrition, Vol. 27, No. 5, 2008, pp. 569-576.

[74] A. Jimenez-Cruz, M. Bacardi-Gascon, W. H. Turnbull, P. Rosales-Garay and I. Severino-Lugo, "A flexible, LowGlycemic Index, Mexican-Style Diet in Overweight and Obese Subjects with Type 2 Diabetes Improves Metabolic Parameters during a 6-Week Treatment Period," Diabetes Care, Vol. 26, No. 7, 2003, pp. 1967-1970. doi:10.2337/diacare.26.7.1967

[75] M. G. Jain, G. T. Hislop, G. R. Howe and P. Ghadirian, "Plant Foods, Antioxidants and Prostrate Cancer Risk: Finding from Case-Control Studies in Canada," Nutrition and Cancer, Vol. 34, No. 2, 1999, pp. 173-184. doi:10.1207/S15327914NC3402_8

[76] C. A. Adebamowo, E. Cho, L. Sampson, M. B. Katan, D. Spegalman, W. C. Willett and M. D. Holnas, "Dietary Falvonols and Flavonol Rich Food Intake and the Risk of Breast Cancer," International Journal of Cancer, Vol. 114, No. 4, 2005, p. 628. doi:10.1002/ijc.20741

[77] USDA-Agricultural Research Service, "USDA National Nutrient Database for Standard Reference,” 2008. www.ars.usda.gov./ba/bhnrc/ndl
[78] Y. I. Kim, "Role of Folate in Colon Cancer Development and Progression," Journal of Nutrition, Vol. 133, No. 11, 2003, pp. 3731S-3739S.

[79] B. M. Patterson and O. A. Levander, "Naturally Occurring Selenium Compounds in Cancer Preventive Trials: A Workshop Summary," Cancer Epidemiology, Biomarkers \& Prevention, Vol. 6, 1997, pp. 63-69.

[80] A. V. Rao and M. K. Sung, "Saponins as Anticarcinogens," American Institute of Nutrition, Vol. 125, No. 3S, 1995, pp. 717-724.

[81] A. Clemente, J. M. Gee, I. T. Johnson, D. A. Mackenzie and C. Domoney, "Pea (Pisum sativum) Protease Inhibitors from the Bowman-Birk Class Influence the Growth of Human Colorectal Adenocarcinoma HT29 Cells in Vitro," Journal of Agriculture Food Chemistry, Vol. 53, No. 23, 2005, pp. 8979-8986. doi:10.1021/jf051528w

[82] A. Obrador, "Fiber and Colorectal Cancer: A Controversial Question," British Journal of Nutrition, Vol. 96, No. 1, 2006, pp. S46-S48. doi:10.1079/BJN20061700

[83] E. Lanza, T. J. Hartmann, P. S. Albert, R. Shields and B. Caan, "High Dry Bean Intake and Reduced Risk of Advanced Colorectal Adenoa Recurrence among Participants in the Poly Prevention Trial," Journal of Nutrition, Vol. 136, 2006, pp. 1896-1903.

[84] E. M. Velie, C. Schairer, A. Flood, J. P. He, R. Khattree and A. Schatzkin, "Empirically Derived Dietary Patterns and Risk of Postmenopausal Breast Cancer in a Large Prospective Cohort Study," American Journal of Clinical Nutrition, Vol. 82, No. 6, 2005, pp. 1308-1319.

[85] T. Agurs-Collins, D. Smoot, J. Afful, K. Makambi and L. Adams-Campbell, "Legume Intake and Reduced Colorectal Adenoma Risk in African-Americans," Journal of National Black Nurses Association, Vol. 17, No. 2, 2006, pp. 6-12. 